\title{
Shiite Survival in Ottoman Aleppo
}

The Endowment Deed (Waqfyya) of Aḥmad and Bahä' al-Dìn al-Zuhrāwì (1066/1656) (Aleppo Court Records, III, pp. 788-79o)

\author{
Marco Salati \\ University of Venice Ca' Foscari \\ salati@unive.it
}

\begin{abstract}
This article presents a translation of a waqf document from the Ottoman archives of Aleppo. The author's contention is this waqfiyya bears witness to the resilience of Shiite presence in a predominantly Sunnite city.
\end{abstract}

\section{Keywords}

Shiism - Aleppo - Aḥmad al-Zuhrāwī - Bahā' al-Dīn al-Zuhrāwī

As anyone who has been there knows, winters in Aleppo can be quite cold and snowy. January 9, 1656 CE was probably one of those winter days that saw the recording of an important, albeit not especially unusual, legal procedure at the court of the Ottoman Hanafi judge. This was the establishment, of a pious endowment of the "family" type (waqf $\underline{d} u r r i \bar{l} / a h l \bar{\imath})$. As elsewhere in the Muslim world, family endowments were common in Ottoman Aleppo. Their popularity was due to their creation of a viable and legal way of permitting the transfer of one's property to a selected circle of heirs, as designated by the donor. The consequence would be that the strict and rather complicated rules of Islamic inheritance could be circumvented. Almost always, as in the case considered here, the male line of the donor's descendants was given preference over the female heirs up to and including the exclusion of the latter. ${ }^{1}$

* Dedicated to the city of Aleppo and those of its people who once were.

1 There is of course a vast bibliography on the various juridical and socio-economic aspects of the waqf institution. I refer the reader to the long and detailed entry Peters, R., s.v. "Wakf", 
What follows is primarily a translation of a specific case with the hope of contributing to the well-established scholarship dealing with waqf documents. ${ }^{2}$ But it also intends to point out the religious peculiarity of this particular waqf deed because it must be understood in the context of the long - albeit at times obscure - Shiite presence in what was and had been a predominantly Sunnite city. Indeed, the document is worthy of attention because it gives us evidence of the resilience of Twelver Shiism in an overwhelming Ottoman Sunni environment. Here we see that the assets and specific stipulations included in the endowment reveal the patrimonial strategies of a typical Aleppine notable clan. Additionally, the document provides a key to the biographies and personal careers of the two donors.

As the main concern of the present article is one particular waqf deed, the reader is directed to other sources on the history of this notable family, the Banū Zuhra/Zuhrāwī. ${ }^{3}$ Therefore only a short discussion of Shiism in Aleppo is necessary here.

$E I^{2}$, XI (2002): pp. 59-99; Baer, G., "The Waqf as a Prop for the Social System", Islamic Law and Society, IV (1997): pp. 264-97.

2 I will limit myself to quoting a few examples from what is a rather extensive list of such contributions: Simsar, M.A., The Waqfyya of Ahmed Pasha (Philadelphia: University of Philadelphia Press, 1940); Panetta, E., "Una waqfiyya hanafita del XVIII secolo", AION, III (1949): pp. 315-30; Munajjed, S., L’Acte de waqf du qāộ̄ 'Uthmān b. al-Munağğà (Damas: IFD, 1949); Vajda, G., "Un act de waqf de Maras", Oriens, v (1952): pp. 47-59; Vesely, R., "Trois certificats délivrés pour les fondations pieuses en Egypte au XVIè siècle", Oriens, XXI-XXII (1968-69)": pp. 248-99; Sourdel-Thomine, J. and Sourdel, D., "Biens fonciérs constitués en waqf en Syrie Fatimide pour une famille de Sharifs Damascains", JEsHO, XV (1972): pp. 269-96; Muhammad Amin, N., "Un acte de fondation de waqf par une Chrètienne ( $\mathrm{X}^{\mathrm{e}}$ siècle h./XVIe s. chr.), JESHO, XVIII/1 (1975): pp. 43-52; Abdel-Nour, A., Étude sur deux actes de waqf du $16^{\mathrm{è}}$ et $17^{\grave{e}}$ siècles des wilayet de Damas et de Sayda (Ph.D. dissertation, Paris, 1976); Abdul Tawab, A. NS Raymond, André, "La waqfiyya de Muștafā Ğa'far", Annales Islamologiques, xiv (1978): pp. 177-93; Crecelius, D., "The waqfiyya of Muhammad Bey Abū al-Dhahab", Journal of the American Research Center in Egypt, Xv (1978): pp. 83-105; Pascual, J.P., Damas à la fin du 16 è siècles d'après trois actes de waqf ottomans (Damas: IFEAD, 1983); Richards, D.S., "A Damascus Scroll Relating to a waqf for the Yūnusiyya", JRAS, CXXII/2 (1990): pp. 267-81; Tate, J., Une waqfiyya du XVII'̉ siècle à Alep. La Waqfiyya d'al-Hāğğ Mūsā al-Amīrī, (Damas: IFEAD, 1990).

3 For a general overview of Shiism in Aleppo see Soberheim, M., "Die Shīa in Aleppo", Der Islam, VI (1915): pp. 95-7; Khayat, H.M., "The Si'ite Rebellions in Aleppo in the 6th AH/12th AD Century", Rivista degli Studi Orientali, XLVI (1971): pp. 167-95; Nașrallāh, I. Halab wa l-Tašayyu' (Bayrūt: Mu'assasa al-Wafā', 1983); Scarcia Amoretti, B., "A proposito della comunità imamita contemporanea di Siria”, oM, III (1984): pp. 193-201; Salati, M., Ascesa e caduta di una famiglia di Ašrāf sciiti di Aleppo: I Zuhrāwīo Zuhrāzāda (160o-17oo) (Roma: Istituto per l'Oriente “C.A. Nallino", 1992): pp. 10-18, 55-65 (Arabic translation, Āl-Zuhrāwī, Irtiqā' wa iktifä' 
Aleppo had a Shiite past which went back to the early medieval era. The local dynasties emerging in northern Syria in the course of the pro-Šisa Buid period (1oth-11th CE), namely the Ḥamdanids and the Mirdāsids, sponsored a clear, although prudent and by no means exclusionary, version of Shiism. As is often the case in the history of Islamic societies, there had been a convenient "rediscovery" of historical sites. In this case, it was those connected to the memory of the Prophet's family which were instrumental in the propagation of the already pervasive 'Alid sympathies within the city's population, sympathies which were were to survive the medieval era and the Shiite rulers of Aleppo well into Mamluk and Ottoman times when Sunnism dominated. There are two such shrines, both located on the Jawšan hill just outside the city walls and only a few hundred yards from each other, the shrine of al-Husayn - the son of 'Ali and martyr of Karbalā' - and that of al-Muhassin (better known in later times as Muhsin) - remembered as the stillborn child of 'Alī and Fāțima rapidly became points of inter-communal, non-discriminatory devotion. It is significant for the history of the city of Aleppo that these essentially Shiite shrines served, in fact, as centres of urban cohesion and identity for all Muslims. ${ }^{4}$

'āila min ašrāf wa nuqabā’ Halab, al-Zuhrāwiyyūn aw Zuhrāzāda, 160o-17oo, Homs: 2007); Id., "Toleration, Persecution, and Local Realities: Observations on Shiism in the Holy Places and the Bilād al-Shām", in La Šía nell'Impero Ottomano (Roma: Accademia dei Lincei, 1993): pp. 121-148; Id., "Š̄isism in Ottoman Syria: A Document from the Qādī-Court of Aleppo (963/1555)", ES, I.1 (2002): pp. 77-84. On the Zuhrāwīs in particular see below footnote n. 12. See also, Douwes, D., The Ottomans in Syria: a history of justice and oppression (London: I.B. Tauris, 2000); Winter, S., The Shiites of Lebanon under Ottoman Rule, 1516-1788 (Cambridge: Cambridge University Press, 2010); Id., History of the 'Alawis from medieval Aleppo to the Turkish republic (Princeton: Princeton University Press, 2016).

4 The shrine (mašhad) dedicated to al-Husayn was erected on the site where it was believed that a few drops of his blood had fallen during the passage of his body on the way to Damascus. The shrine of Muhassin/Muhsin commemorated the tragic, albeit obscure, event of Fatima's miscarriage. See Massignon, L., s.v. "al-Muhassin", $E I^{2}$ : VII (1995): p. 468; Sauvaget, J., "Deux sanctuaires chiites à Alep", Syria, IX/3 (1928): pp. 225-37, IX/4 (1928): pp. 320-7; Soberheim, M., "Das Heiligtum Šayh Muhassin in Aleppo", in Mélanges $H$. Deremborg (Paris: 1940): pp. 379-90; Herzfeld, E., Materiaux pour un Corpus Inscriptiorum Arabicarum: deuxième partie: Syrie du Nord - Iscriptions et monuments d'Alep, I-II (Le Caire: IFAO, 1954); Mulder, S., The Architecture of Coexistence: Sunnis, Shi'is, and the Shrines of the 'Alids in the Medieval Levant (Ph.D. dissertation, University of Pennsylvania, 2008): pp. 61-95; Id., The Shrines of the 'Alids in Medieval Syria: Sunnis, Shi'is, and the Architecture of Coexistence (Edinburgh: Edinburgh Series in Islamic Art, 2014); Allen, T., Ayyubid architecture, online publication, 2009, chap. 4-5 (http://www.sonic.net/ tallen/palmtree/ayyarch/; retrieved January 2017). 
Up until the Mamluk era, Aleppo drew the attention of historians and chroniclers for the presence of a significant Shiite community that included a considerable number of religious scholars, among them the Banū Zuhra. This family clan, the progeny of the celebrated Shiite Imām Ja'far al-Ṣādiq descending from his son Ishāa al-Mu'tamin, ${ }^{5}$ had settled in Aleppo from the region of Harrān in northern Mesopotamia around the second half of the 1oth century. It is possible that this move had been encouraged by the pro-Shiite Aleppan rulers at the time. In a relatively short period the Banū Zuhra managed to become an essential component of the city's influential leadership. This is revealed in a number of developments: the appointment of several members of the clan to top positions in the city's administration and their virtually uninterrupted incumbency as head (naqib) of the fast-growing segment of the population claiming descent from the Prophet (al-ašrăf). ${ }^{6}$ The number of buildings and sites associated with them also attests to their eminence. ${ }^{7}$

The advent of the Mamluks in the second half of the 13th century heralded a marked decline for the Banū Zuhra in particular and the Aleppine Shiites in general. The diminishing number of entries for them in biographical repertories and local chronicles, coupled with the relocation of some of them to the countryside $^{8}$ and the realignment of several others to Sunnism of the Shafiite persuasion, is clear evidence that the times had changed for the followers of

5 See Salati, Ascesa e caduta: p. 10. This Isḥāq al-Mu'tamin was married to Nafīsa bt. al-Ḥasan who eventually acquired much greater fame as one of the most venerated holy figures in Cairo.

6 For the biographical entries on the Banū Zuhra see Salati, Ascesa e caduta: pp. 129-39. On the niqāba al-ašr $\bar{a} f$ and the ašrā $f$ in general see Havemann, A., s.v. "Nakīb al-Ashrāf", $E I^{2}$, VII (1993): pp. 926-7; Morimoto, K. (ed.), Sayyids and Sharifs in Muslim Societies: Living Links to the Prophet (London: Routledge, 2012); Id., "A Preliminary Study on the Diffusion of the Niqāba al-Tālibiyyīn: Towards an Understanding of the Early Dispersal of Sayyids", in Kuroki, H. (ed.), The Influence of Human Mobility in Muslim Societies (London-New York-Bahrain: Routledge, 2003): pp. 3-42; Canbakal, H., "The Ottoman State and Descendants of the Prophet in Anatolia and the Balkans", JESHO, LII (2009): pp. 542-78. For a list of the naqïbs al-ašrä $f$ of Aleppo in the $17^{\text {th }}$ century see Salati, M., "Note in margine alla storiografia musulmana su Aleppo: una lista di naqīb al-ašrā fdel XVI e XVII secolo”, Rivista degli Studi Orientali, LXIX/3-4 (1990): pp. 381-6.

7 In particular, two madrasas, two masjids, a pavilion later converted to a Sufi zāwiya, a graveyard next to the shrine of al-Husayn, one hammām, one orchard, a walkway (darb), two family residences (see Salati, Ascesa e caduta: pp. 12-3).

8 A stronghold of Syrian Shiism to this day, the village of al-Fū'a, a few kilometers east of Idlib, became a refuge for the Shiites of Aleppo, including some branches of the Banū Zuhra, early on in the Mamluk era (see Salati, M., "I villaggi imamiti della provincia di Aleppo in epoca ottomana", Rivista degli Studi Orientali, LXIII/4 (1989): pp. 231-55). 
'Alī and his ever-increasing offspring. ${ }^{9}$ Politically and otherwise the Shiites of Aleppo were thereafter disadvantaged, but they were far from extinct. It was politic to practice taqiyya - that is, dissimulation of one's faith under duress. This enabled them to conform to the prevailing religious exigencies of the day while surviving. Albeit much fewer in numbers and unacknowledged, Aleppine Shiites survived into the Ottoman era, a fact alluded to and sometimes laconically recognized in the literary historical material that covers the long Ottoman rule over Syria. ${ }^{10}$

For historians, however, research in the all-important local court records (sijillāt al-mahākim al-šar'ìya) has made it possible for us to at least partially fill the gaps in the history of the Banu Zuhra - and consequently of Shiism in Ottoman Aleppo - at least from the mid-17th to the mid-18th century. ${ }^{11}$ From these we learn that in the 1630s, the Banū Zuhra reappear in the persons of two brothers, Aḥmad, the senior, and Bahā' al-Dīn al-Zuhrāwī, or Zuhrāzāda,

The shift to Sunnism of several of the Banū Zuhra is clearly detectable in the biographical entries recorded in the literary sources (see Salati, Ascesa e caduta: pp. 129-39). This sort of connection between Shafiism and Shiism, whereby the former was used by the latter as a useful cover, is intriguing but still awaits thorough investigation. In our case, this is clear from what is recorded about the first of the Banū Zuhra allegedly to arrive in Aleppo, Abū Ibrāhīim Muhammad famous as "the much praised" (al-namdūḥ): "The people of Aleppo were all Hanafites and knew no other doctrine until a man arrived from 'Iraq. Then Shafiism and Shiism began to spread among the population, because they [the Shiites] make use of the doctrine of Šāfi'ī as a cover" (al-Ṭabbāh, M.R., I'lām al-nubalā bita'rīkh Ḥalab al-Šahbä' (7 vols., Ḥalab: Dār al-Qalam al'Arabī, 1988/1408²): I, p. 446, reporting a passage of the historian Ibn al-Hanbalī, d. 1563).

Of the forty-seven entries on the Banū Zuhra recorded in the literary sources, only seven pertain to the Ottoman period. The last ones to be mentioned, with very few details, date to the first half of the 17th century (see Salati, Ascesa e caduta: pp. 138-139).

On the Ottoman Court Records, their nature and typology see Faroqhi, S., s.v. "Sidjill 3", $E I^{2}$, IX (1997): pp. 539-45; Algunduz, A., "Shari'ah Courts and Shari'a Records: The Application of Islamic Law in the Ottoman Empire", Islamic Law \& Society, XVI (2009): pp. 202-30; Ze'evi, D., "The Use of Ottoman Shari'a Court Records as a Source for Middle Eastern Social History: A Reappraisal", Islamic Law \& Society, v (1998): pp. 35-56. For the court records of Syria see Rafeq, A.K, "The Law-Court Registers of Damascus", in Berque, J., and Chevallier, D., (eds.), Les Arabes par leurs Archives, XVI-XX s. (Paris: CNRs, 1976): pp. 14159; Marino, B., Dalïl sijillāt al-mahạkkim al-šar'iyya/Cataloues des Registres des Tribunaux Ottomans (Damas: IFEAD, 2000). 
as they were called in these documents. ${ }^{12}$ The list of Ahmad's honorific titles, ${ }^{13}$ various administrative functions, ${ }^{14}$ diversified business activities and properties both in Aleppo and in the countryside, ${ }^{15}$ clearly qualified him a fullyfledged component of the restricted circle of urban notables. ${ }^{16}$

12 See Salati, Ascesa e caduta: pp. 67-109; Id., "Urban Notables, Private Waqf and Capital Investment: The Case of the 17th Century Zuhrāwī Family of Aleppo", Le Waqf dans l'éspace islamique. Outil de pouvoir socio-économique (Damas: IFEAD, 1995): pp. 187-201; Id., "Nuovi documenti sui Zuhrāwī/Zuhrazāda di Aleppo (1699-1710)", Annali di Ca' Foscari, xxxvıI/3 (1998): pp. 115-53; Id., "Ancora sui Zuhrazāda/Zuhrāwī di Aleppo: nuovi documenti dai tribunali sciaraitici (1706-1736)", Annali di Ca' Foscari, XLVI/2 (2007): pp. 73-108; Id., "Un ultimo documento sui Zuhrāwīzāda di Aleppo proveniente dai registri dei tribunali sciaraitici (1169/1751)", in Bredi, D., Capezzone, L., Dahmash, W., and L. Rostagno (eds.), Scritti in onore di Biancamaria Scarcia Amoretti (3 vols., Roma: Edizioni Q, 2008): III, pp. 1049-55; Id., "Note in margine ai Banū Zuhra/al-Zuhrāwī/Zuhrazāda di Aleppo: alcuni documenti dai tribunali sciaraitici della fine del XVII e l'inizio del XVIII secolo (1684-1701)", Annali di Ca' Foscari, XLIX/3 (2010 [Serie orientale, 41]): pp. 23-42; Id., "Un documento sull'uso della hisba dai registri dei tribunali sciaraitici di Aleppo (1070/166o) conservato nella Biblioteca Nazionale 'Cirillo e Metodio' di Sofia”, in Papa, M., Scolart, D., and Piccinelli, G.M. (eds.), Il Libro e la Bilancia. Scritti in memoria di Francesco Castro (2 vols., Roma: Istituto per l'Oriente "C.A. Nallino", 2011): I, pp. 299-304; Id., "Tre documenti sull'uso della jizya nella Aleppo ottomana del XVII secolo", om, XCIV (2014): pp. 176-85.

13 See for example the titles by which he is described in the waqf text below. The family name Zuhrāwī was often translated in the Ottoman form Zuhrazāda (sometimes also Zuhrāwīzāda), the Persianate $z \bar{a} d a$ standing as the indicator of high status in Ottoman Syria.

14 As naqīb al-ašrā $f$ he was entitled to manage the famous waqf of Ipšir Paša (established 1654), and the waqf for the ašräf of Aleppo, which dated back to the Mamluk era. For a few years, he also held the administration of the waqf for the Two Holy Cities of Mecca and Medina in the province of Aleppo, and acted as qassām 'askarī (a court-appointed distributor of inheritance shares), two influential positions usually reserved for members of the Ottoman military class. He also received a daily salary for "reciting prayers" (du'áji) and was entitled to a yearly allowance from the $q \bar{a} d \bar{\imath}$ ship of Jerusalem.

15 See the complete list of his properties and business activities in Salati, Ascesa e caduta: pp. 157-8.

16 When dealing with the 16 th and 17 th centuries, as we are here, I think it is necessary to be wary of using the term a'yān, generally translated as either "notables" or "élite", since the term involves some ambiguity. I concur with Reilly when he points out that "the term needs to be disaggregated according to a distinction drawn by J. Clancy-Smith between "élites" and "notables" [...] Elites drew some, though not all, of their political authority from relationships with the state. Religious notables on the other hand tapped deep into other sources- sharifian descent, special piety, erudition, charity ... the attributes demanded of the holy person. They wielded socio-spiritual and moral authority [...]. The respective bases of authority often were intertwined, but the basic distinction between 
That the two brothers held on to the religious identity of their ancestors is something not immediately evident in the literary sources. Both al-Ġazzī and al-Tabbāh - the two early 2oth century historians who dominate in the historiography of Aleppo - give only incidental information on the subject at best. The first observes that "around the year one thousand of the hijra the Shiites of Aleppo took to disguising themselves and behaving like Sunnis. By doing so they managed to obtain [both] the favour of the rulers and high positions, which they then secretly used to harm the Sunnis. However, after Muștafā Tahazāda crushed them, they went into hiding again".17

The second author mentions the Banū Zuhra/Zuhrāwī within the biographies of two members of the Kawākibì family, indicates that there were matrimonial links between the two families, noting also that the Banū Zuhra held the niqāba as late as the 11 th / 17 th century. ${ }^{18}$

All in all, this is intriguing but far from complete and conclusive evidence of the survival of Shiism in Aleppo. Therefore, evidence from the court records, as mentioned above, allows us to clarify and augment the picture inasmuch as they present Aḥmad al-Zuhrāwī holding the leadership of the ašrāa - which was by all means a key position in Ottoman Aleppo - for many years in the

people of the military and scholarly/religious status is relevant to the social structure of Ottoman towns including Hama [...]. Elites owed their ascendancy to connections to the Ottoman state, forming a kind of aristocracy of service. Notables, in addition to their connection with the state, possessed autonomous cultural capital that flowed from their illustrious ancestry, their religious learning, and their association with mosques and Sufi lodges that they or their ancestors had founded" (Reilly, J., A small town in Syria. Hama in the 18th century (Oxford and Bern: Peter Lang, 2002): pp. 25-6, 135-6, brackets mine). See also the pioneering studies of Hourani, A., "Ottoman Reform and the Politics of Notables", in Polk, W.R., Chambers, R.L., (eds.), Beginnings of the Modernization in the Middle East: The Nineteenth Century (Chicago and London: The University of Chicago Press, 1968), pp. 41-68; Schilcher, L., Families in politics: Damascene factions and estates of the 18th and 19th centuries (Stuttgart: F. Steiner Verlag, 1986). See also Masters, B., The Arabs of the Ottoman Empire, 1516-1918: A Social and Cultural History (Cambridge: Cambridge University Press, 2013); Meriwether, M.L., The Kin Who Count. Family and Society in Ottoman Aleppo, 1770-1840 (Austin: University of Texas Press, 1999).

17 Al-Ġazzī, K., Nahr al-dahab fì ta'rīh Halab (3 vols., Halab: Dār al-Qalam al-'Arabī, 1999²): I, p. 192. On the Tahazāda family see Wilkins, Ch., Forging Urban Solidarities. Ottoman Aleppo 1640-17oo (Leiden: Brill, 2010); Id., "The Self-Fashioning of an Ottoman Urban Notable: Ahmad Efendi Tahazāde (d. 1773)", Jos, XLIV (2014): pp. 393-425.

18 Al-Ṭabbāh, I'lām al-nubalä' IV, p. 286; VI, p. 466; VII, p. 107. 
mid-17th century, ${ }^{19}$ only to lose it to the very same Muștafā Tahazāda mentioned by al-Gazzī.

In Ottoman times and generally for Muslim families, the creation of a family waqf - being something like a private foundation - was a common practice whereby affluent families could at least hope to secure their properties and assets in perpetuity. ${ }^{20}$ The two Zuhrāwī brothers are no exception here. Having succeeded in strengthening their social and political standing among the urban élite, and in consolidating the family's wealth, they proceeded to make good use of the facilities allowed by the waqf. So much so that we know of not just one but two nearly contemporaneous waqf deeds signed by the two brothers. The first, dated 1064/1654, ${ }^{21}$ comprises a number of properties, including two houses and several plots of land outside the city's wall, and also the ownership of some shares of a soap factory in Idlib.22 The second, as will be seen below, includes a whole soap factory and a plot of uncultivated land.

However, something sets the Zuhrāwì endowments apart from all the others that we know from Aleppo. Specific terms laid down by the two donors in both their waqf documents reveal that if the line of designated beneficiaries becomes extinct, half of the waqf is to be transferred to benefit the shrine of Muhassin/Muhsin in Aleppo. Here we see that the Zuhrāwī acknowledged and supported the long tradition which made the two 'Alid shrines the common heritage of all the inhabitants of the city, irrespective of religious affiliations. There is nothing remarkable about this clause, except, perhaps, the fact that,

19 His years of tenure, as can be ascertained from the court records, are 1639-1642, 1648-49, 1653-1662, 1663-64, 1665-66. His son Hasan Zuhrāwī succeeded him twice in 1662-63 and 1664-65, a clear indication of the extent of power and influence exercised by the family.

20 For Aleppo see Masters, B., The Origins of Western Economic Dominance in the Middle East: Mercantilism and the Islamic Economy in Aleppo, 1600-1750 (New York and London: New York University Press, 1988); Marcus, A., The Middle East on the Eve of Modernity. Aleppo in the 18th century (New York: Columbia University Press, 1989); Meriwether, The Kin Who Count.

21 A rough draft of this document is, or was, preserved in one of the Aleppo Waqf Registers (n. 1, pp. 105-106). Until the early 9o's, at least, they were stored in the Mudīiriyya al-Awqāf of Aleppo, at that time a modern building facing the Citadel. See Salati, M., Documenti giuridici aleppini dei secoli XIV-XVII in materia di waqf (Roma: Istituto per l'Oriente "C.A. Nallino", 1991): pp. 49-61.

22 Some 6o kilometres west of Aleppo, the town of Idlib was famous for soap and oil production. See Qūṣarā, F., al-Rahhhāla fìmuhāäfaza Idlib (2 vols., Dimašq: 1985-88); al-Ġazzī, Nahr al-d̂hah: I, pp. 517-28; al-Ṭabbāhn, I'lām al-nubalā': III, pp. 273-86; Salati, Ascesa e caduta: pp. 99-102. 
to my knowledge a stipulation of this kind is not encountered elsewhere in the extant court records.

But what then of the other half if the waqf once the family is extinguished? It is here that we find something rather unique and out of the ordinary. The two brothers give clear instructions that it is to benefit the financing of the visit (ziyāra) to the shrine of Husayn at Karbalā'. To the present writer this seems significant and revealing. Here we have a perfect piece of evidence needed to resolve the matter of the Shi'ite presence in Ottoman Aleppo and the identification of the Shiites with the Banū Zuhra/Zuhrāwì. Nowhere in the list of the waqfs of Aleppo compiled by al-Gazzī do we find anything like it, nor, in my experience, does anything in the court records so clearly confirm the link. ${ }^{23}$

The sudden rise of a powerful competitor, the Tahazāda clan, on the one hand - as indicated by al-Giazzī and indirectly confirmed in the court records and the gradual appropriation of the Zuhrāwīs' assets by the Kawākibī family through matrimonial relationships - a process made easier by the extinction of the male line of the Zuhrāwīs around the mid-18th century - was to put an end to any significant visible forms of Shiite presence in Aleppo until very recent times.

\section{The Document}

That which is within this legal volume and inside [this] lawful... [illegible] with regard to the foundation of the waqf, its precepts and stipulations, the dedication to charitable purposes, its provisions and expenditures, as was expounded and set forth in detail in its lines in the manner established and explained therein, was proven valid and confirmed before me. I have therefore ruled for its validity and legally binding character, well aware of the existing disagreement among the eminent masters [of the schools of Law] regarding the waqfs, and taking into account what is necessary to consider with respect to the glorious scholars.

'Abd al-Bāqi, most humble of all mankind, who is delighted to be serving the pure Law, the judge of the city of Aleppo ${ }^{24}$ - may it be honored with joy and good fortune and preserved from harm and misfortune untilJudgment Day - recorded it. May the Lord, the much-forgiving, pardon him.

23 For this list see al-Ġazzī, Nahr al-dahab: II, pp. 535-630. Al-Gazzī takes notice of this peculiar stipulation but does not elaborate on it.

24 According to al-Ġazzī Nahr al-dahab: I, p. 306, 'Abd al-Bāqī is mentioned as Hanafite judge for the year 1065/1654-55. Ḥusnī Paša Mușțafã is the judge in charge for the year $1066 / 1655-56$. 
In the name of God, the Compassionate, the Merciful, on Him we rely,

Praise be o God, in Whose divinity's vast expanse the minds of the erudite are confounded, and in imagining His might discerning intellects are confused, while every pearl of Heaven and Earth reflects his Oneness, while He makes easy for those who serve Him the accomplishment of what they choose of good deeds so as to grant them His approval.

The prayer and peace may be upon His chosen Prophet, His selected messenger Muhammad, may God pray for him and save him, in prayer and in peace for as long as Heaven and Earth will last.

At the Court of the noble Law,

At the Assembly of the honorable religion,

Before its protector, the model of the illustrious, the pillar of the great, the compiler of legal matters and of the ordinances, he who solves the difficult problems of mankind, the man of many virtues and enlightened proofs, the arbitrator of the Law of Muhammad, the servant of the religion of Muhammad, he who abolishes the false innovations, the defender of the Muslim community, he who places his noble names with his elegant script; ${ }^{25}$

there appeared the two full brothers, [the one] the pillar of the learned and of the noble sayyids, the cream of the excellent ones of the glorious ašrāf, the model of the mantle of Muhammad, the fruit of the tree of Muhammad, his Excellency and our lord, sayyid Aḥmad afand $\bar{\imath}^{26}$ al- Zuhrāwī, the naqīb al-ašra $f$ of Aleppo at the time; ${ }^{27}$ [the other] the cream of the noble sayyids, sayyid hâjjj Bahā' al-Dīn jalab̄̌. ${ }^{28}$ They both are the sons of the late noble and illustrious sayyid, he who passed away towards the mercy of his Lord the Compassionate, Ibrāhīm afand̄̄ al-Zuhrāwī, the naqīb al-ašrā $f$ of Aleppo in his lifetime. ${ }^{29}$ Together they established a waqf which is comprised of the properties listed inside this esteemed written document. They both have called

25 On Ottoman honorific titles for Pashas and judges see Bayerle, G., Pashas, Begs and Effendis. A Historical Dictionary of Titles and Terms in the Ottoman Empire (Istanbul: IsIs, 1997); Tülüveli, G., "Honorific titles in Ottoman parlance", International Journal of Turkish Studies, XI (2005): pp. 17-28.

26 This title was generally applied to educated members of the religious class.

$27 \quad$ See above p. 211 and note 19

$28 H a \bar{a} j j$ indicated a person who had performed the pilgrimage to Mecca. The title jalabi (Turkish çelebi), was used in Aleppo to designate merchants and educated people in general who were not religious scholars.

29 This Ibrāhīm is not mentioned in the biographical sources and I have not found any references to him in the extant court records. His alleged tenure as naqīb al-ašrăf of Aleppo therefore cannot be verified. 
upon the witnesses mentioned below on their behalf ${ }^{30}$ to the effect of declaring to have established as eternal, perpetual, and permanent waqf, in good intention and in sound mind, what is included in their property in equal portions, without there being any legal adversaries or opponents. [The property is as follows]:

All of the soap-factory, in good condition and functioning, located in the prosperous town of Idlib "the Lesser", in its northern quarter, and which they built with their own money and for themselves in equal portions. They had purchased [the property] when it was nothing but a piece of land, known as al-Hayya $\bar{r}$ a, surrounded by a wall and with an underground space, from:

Muștafā jalabī b. [i.e. the son of] Aḥmad beše, who acted as his own legal agent; ${ }^{31}$

his brother Muhammad jalabi who acted as his own legal agent and as the legal representative of his mother sitt Halab bint [i.e. the daughter of] hăjjj 'Izz al-Dīn and of his sister 'Ābida bint Aḥmad beše, upon confirmation of his proxy on their behalf by way of legal and just evidence according to the Law;

Mahmūd bayk ${ }^{32}$ b. hăjjj Abū Zayd, the legal representative of his mother Farah bint Aḥmad beše whose proxy on her behalf was certified according to the Law by way of legal and just proof;

and 'Ali bayk b. Yildirim the janissary.

They all are residents of the above-mentioned town according to what is recorded in the legal document in their possession and produced in Court, dated the 29th of Jumādā II of the year 1065 [/6 May 1655], which bears the signature of the model of Islamic judges, the treasure of the rulers of mankind, our lord Muștafā afandī b. Muhammad, the judge of the above-mentioned town. ${ }^{33}$

[The waqf is also comprised of] the piece of land known as Nisf al-Majlis which came into their possession by way of legal purchase from 'Alī bayk b. 'Abdallāh, as attested by the legal document in their possession. They added

$30 \quad$ For the expression ašhada 'alā nafsihi fulān ${ }^{a n}$ see Vesely, R., "Les requêtes en Egypte au XVIè siècle", REI, XLV (1977): p. 207; Id., "Trois certificats": pp. 260, 298-9; Powers, D.S., "A court case from 14th century North Africa", JAOS, CX/2 (1990): p. 251; Little, D.P., "Haram documents related to the Jews of the late fourteenth century Jerusalem, Journal of Semitic Studies, xxx/2 (1985): pp. 227-264, here p. 259.

31 A title used for rank-and-file soldiers. It has been suggested that it is the result of the contraction of bāšà $\bar{g}$, see Marino, B., Le faubourg du Midan (Damas: IFEAD, 2002): p. 150.

32 Beše was a title applied to middle-ranking military personnel.

33 I have not been able to identify him. However, his very presence confirms the status of Idlib as a vital provincial centre in the Ottoman period. The town was divided into two sections, "the Greater" (al-kubrā) and "the Lesser" (al-șugrrā), the latter being, ironically, more important. 
it to the piece of land called al-Hayya ara with the authorization to build whatever they should wish on the above-mentioned piece of land to remain in their permanent ownership, free to dispose over and manage it as they wish. The authorization was granted them by the woman called sitt Rahma bint Husayn, the administrator with full rights from her grandfather's waqf, the late Šayhūn al-Saalihịi, of which all the said town is part. ${ }^{34}$ This was done by virtue of a document of authorization produced by them, dated the 17th of Rajab 1065 [/23 May 1655] and signed by the model of the meritorious scholars, our lord Ibrāhīm afandī famous as Ṣalāḥzāda, the judge of Aleppo. ${ }^{35}$

The document contains his acknowledgment of the legal nature of the selling carried out by the sellers and the building authorization given to the abovementioned brothers in conformity with what was explained.

The soap-factory includes two large copper cauldrons ( $q i d r$ ) weighing three qințār halabi ${ }^{36}$ which they had repaired and renovated with their own money; forty new cisterns, which they quarried and reconstructed for the storage of olive oil, four new water cisterns, one watermill, nine chambers (awda?),,7 eight iron buckets, one platform scale, the above-mentioned underground cave, an open-air courtyard, and two new ovens for the two cauldrons. It also includes conveniences, accessories, and the legal rights [to these].

It is bordered to the south by the house of 'Abd al-'Aziz and the house of $h \bar{a} j j$ Ahmmad, and completely by the bayt al-Ašqar; to the east by the courtyard which is the property of the two donors, and by the al-Baydar land; to the north by the road, a part of which divides the soap-factory from the piece of land mentioned below, and that is where the entrance to the soap-factory is; to the west by the soap-factory a part of which belongs to the [other] waqf established by the above-mentioned two brothers [in the year 1064/1654]. It is known as the al-Ṭūbāl soap-factory. ${ }^{38}$ The rest of the al-Ṭūbāl soap-factory is the property of their sister's son, the pillar of teachers and of ašrāaf, the noble

34 Here the land upon which the town stood is probably meant. The Šayhūn waqf included a small portion of Sarāqib, another relatively important town in the rural north-west of Syria: see Venzke, M., The Ottoman Sanjaq of Aleppo (Ph.D. dissertation, Columbia University, New York, 1981): p. 309.

35 Not identified. He is not mentioned in the list of Ottoman Hanafĩ judges provided by al-Ġazzī.

36 Made up of one hundred rațl (one rațl equals roughly two kilos) the qințār of Aleppo was used both for solids and liquids. The qințār of Idlib, weighing a little more than that designated halabì, was specifically used for soap.

37 The text is not clear.

38 On this particular soap-factory see Salati, Ascesa e caduta: p. 101; Id., Documenti giuridici aleppini: pp. 51-2, 59 . 
sayyid Fathallāh jalabī [al-'Arīî], ${ }^{39}$ and of the sons of Aḥmad beše. [The waqf] is also bordered completely by the soap-factory of Ahmad beše which is known as the soap-factory of hājj Abū l-'Uzz.

[The said waqf is also comprised of] all the piece of land, which is vacant and barren, known as al-Marāh to the north of the soap-factory. It was transferred to them [i.e. the founding brothers] by way of legal purchase from the young man by the name of Jibrīil b. Muhammad, who acted as his own legal agent and as the legal representative of the two full-sisters Bākiya and Iḥsān, upon confirmation of his proxy on their behalf by way of legal and just evidence, in conformity with what is reported in the legal document in their possession which bears the date of the 19th of Du l-Qa'da of the year 1065 [/20 September 1655]. It was signed by our lord the above-mentioned Muștafā afandī the judge of the said town. It is bordered to the south by the road that separates it from the said soap-factory; to the east by the property of hājj Nașrallāh; to the north by the property of Muștafā al-Zahrān; to the west by the property of the said seller.

All of this [the soap factory and the piece of land] with its borders and the whole of its rights that are within and without it, [now] constitutes a legal and legitimate waqf, it is an authentic and lawful pious donation, closely connected in its beginning, middle, and end.

The waqf is established initially for the benefit of the two of them during their lifetime, for as long as they live, without sharing nor opposition from anyone, and equally; ${ }^{40}$ then, after each of them, and after a long life, half of what was mentioned above will be for the benefit of their respective surviving children from their offspring, male and female, according to the prescribed legal shares.

This is so arranged on the condition that if a daughter from the offspring of one of the two founders should marry after this, she would lose her rights for as long as she is married; were she already married, she would have no rights whatsoever, whereas were she unmarried or without a husband she would

39 The 'Arīfí clan of wealthy merchants was related to the Zuhrawī. This Fathallāh in particular was the son of Aḥmad al-Zuhrāwī's sister, and Aḥmad himself had married an 'Arīfí woman, Raḥma. The most famous 'Arîfī was Yūsuf b. Șalāḥ al-Dīn who held the office of Head of Merchants (šāhbandar) around 1669-1671. He had married Ahmad's daughter, Hadija (see Salati, Ascesa e caduta: pp. 69-71).

40 The schools of Law disagree as to whether the founder may be the beneficiary of his own trust since establishing a waqf "implies the transfer of the right to dispose of and the right to use the wakf property. Retaining (part of) the right to use it is in conflict with this principle" (Peters, R., s.v. "Wakf", $E I^{2}$, XI (2002): p. 61). The Ḥanafîs, nonetheless, approve if its validity. 
benefit from what has been established together with her brothers. If one of their daughters should marry, her right to the profits of the waqf would fall to the benefit of her brothers. Had she been then without a husband she would get her share back, but if she should (re-)marry, her rights would again revert [to her brothers].

The children of their daughters, both male and female, have no rights to the said waqf if their (the two donors') male children, and the sons of their (the two donors') male children and the sons of the sons of the sons of their (the two donors') male children are still alive.

Then, following the two donors' male children, the waqf will benefit his ${ }^{41}$ children, the males to the exclusion of the females, in equality and without favoring one over the other brother; then, their children's children, and their children's children's children, the male ones, and so on, generation after generation, time after time.

The children will receive nothing as long as their father is alive. If one of the male children, from among the children of one of the two donors, should die before benefitting of the said waqf, leaving one or more sons, then this son or these sons will benefit of what his/their father would have enjoyed when alive, according to his/their share of inheritance.

If the male line of one of the two donors should die out with no one left of the constituent's descendants solely in the male line, then half of the half [of the waqf's proceeds], that is one-fourth, will go to the surviving sons of the females from among the descendants of the donor whose descendants in the male line had died out. This according to the legal prescription of the law of inheritance that gives the male the share of two females.

The remaining half of the half, that is one-fourth, will go to the male children and their male children from among his [one of the donor's] brother's children in equal shares.

Should there be no one from among the children of the females' descendants of one of two (i.e. the donors), after the extinction of the males and of their male children, then half of the it will go his brother's surviving children from the progeny of the males.

If one-fourth [of the waqfs proceeds] has gone to the children of the females' descendants of one of the two donors after the extinction of the male line, and when also the children of the females would be extinguished, then this one-fourth will also go to the male children of the brother's male children, in addition to the rest of the waqf.

41 The wording of this passage does not seem to be consistent. "Their children" (awlädihim) makes more sense. 
Should the male children in the male line from the progeny of both the two donors die out, then the waqf will go to the children of the female descendants of the two donors, according to the legal prescription of the law of inheritance that gives the male the share of two females, then to their children, male and female, then to their children's children, accordingly.

In case of the total extinction [of any progeny from the two founders], and should the earth be void of anyone related to the progeny of either of the two donors, then half of the waqf will be for the benefit of [those who] visit the shrine of the Lord of the Martyrs, the Cave of the Țâlibīs, the Magnanimous Imām, his Excellency the Imām al-Husayn, son of the Commander of the Faithful, the Magnanimous Imām, the Master Lion, the Victorious Lion of God, the Imām 'Alī b. Abì Ṭālib - may God be pleased of them all - which is in Karbalā'. The other half will be a waqf for the benefit of the shrine of the Imām sayyid Muhassin, may God be pleased with him, which is outside [the walls of] the city of Aleppo.

Should it not be possible to deliver the profits from the half of the waqf to the said shrine [of Karbalā'] as a result of the interruption of communications, then the whole waqf will be for the benefit of the shrine of the Imām Muhassin in Aleppo.

Should it be impossible for the shrine of the Imām Muhassin to benefit from this waqf, then the whole waqf will be for the benefit of the shrine of Karbalä' But should the delivery of the profits to the advantage of the shrine of Karbalā' be impossible, then the whole waqf will benefit the poor among the Muslims of Aleppo. ${ }^{42}$

So be it forever and ever and for all eternity, until the time that God will inherit the Earth and everything in it, since "He is the best of inheritors". 43

The two mentioned-above donors stipulate that the administration of their waqf will be the responsibility of the perfect sayyid, his Excellency Ahmad afandī during his life, whereas the supervision will be the responsibility of his brother sayyid hạjjj Bahā' al-Dīn jalabì. Should one of them die, the administration will fall to the remaining brother, and the most senior among the children of the deceased will act as supervisor. ${ }^{44}$

42 According to the Hanafĩ school (with the notable exception of Abū Ḥanīfa) "it is required for the validity of a wakf that the designation of the beneficiaries should include a final class whose existence is regarded as perpetual, such as the poor": Peters, s.v. "Wakf": p. 61. A reference to Qur'ān 21:89.

44 For the Ḥanafĩ school, and Abū Ḥanīfa in particular, it is permissible for the constituent to appoint himself as waqf administrator (mutawallī) during his lifetime. 
After their (the two donors') passing, the senior-most of the children of whoever of the two [brothers] will act as administrator, the senior-most of the children of the other brother will act as supervisor. Should the waqf go to the children of the female descendants after the extinction of the male children, the senior-most, and so on, of the progeny of the female descendants will be the administrator, and the senior-most, and so on, of the progeny of the other [brother's] female descendants will be the supervisor.

Should the waqf go to one of one the two donors' children, the senior-most of them will be the administrator, while one of the others will act as supervisor.

Should the waqf go to the two shrines, the administrator of the shrine of the Imām Muhassin will manage it and the administrator of the shrine of Husayn will act as supervisor.

Should it go to the poor, then their $q \bar{a} d \bar{l}$ in charge at the time will be the administrator. ${ }^{45}$

They also stipulated that the administrator after them is to take care of it by making use of the waqf income and what remains of it... [illegible]), increase of his salary. Every year he will use ten girsh riyāl from the profits of the said soap-factory for the benefit of the poor of Medina the Illuminated - the best prayer and salute upon her. He will entrust this sum year after year at the departure of the Syrian pilgrimage caravan with a Muslim merchant who will distribute it there. ${ }^{46}$

Every year he (the administrator) will deliver five rațl of pure olive oil to the administrator of the waqf of the Great Mosque erected for the mention of God's name in the said town..$^{47}$ The oil will be used to light up the mosque during the blessed month of Ramadian.

He will also pay every month a half girsh asadī for a Qur'anic reader to read every day selections of the Noble Qur'ann... [illegible]. He will dedicate the reward resulting from this to the soul of noblest of God's messengers - may God pray for him and save him - to the soul of the two donors, their father and the deceased Muslims.

According to Islamic Law, the $q \bar{a}$ di $\bar{\imath}$ was the ultimate supervisor in case of extinction of the line of administrators designated by the donor.

46 Although the aqçe ('utmānī, in the Arab lands) was the official Ottoman coin, two silver coins of European origin were generally used as of the 17 th century, the $\dot{g} i r s h$ asadi and the girsh riyālì, approximately equaling 80 and 120 'uțānī respectively, at least in the period under consideration. See Masters, Western Economic Dominance: pp. 150-1; Johnson, B.D., The Ottoman currency system (1687-1754) (Ph.D. dissertation, University of Washington, 1999).

That is Idlib "the Lesser". 
Should anything remain after all this, it will be divided among the beneficiaries as heretofore established. The two founders appointed ${ }^{48}$ [the so-and-so administrator of the said waqf so as to bring it to completion and make it effective on the condition of retaining the right to dismiss him at any time should they so wish. They turned the waqf over to him and he accepted it.

Then the said founders wished to contest their waqf adducing as evidence that according to the opinion of the Great Master Abu Haniffa - may God be pleased with him - the waqf is not legally operative and effective. The administrator appointed for the registration of the waqf opposed them in this matter by stating that even if the waqf is not legally operative and effective according to the opinion of the said Master, it is so nonetheless valid according to the opinions of the two Great Masters, Abū Yūsuf and Muhammad al-Šaybānī may God have mercy on them in this world and in the hereafter. When the two parties argued and debated before the judge, the administrator requested a ruling in favor of the validity of the waqf and its permissibility according to the opinions of the said two Masters. Then the judge complied with his request, accepted his claim and ruled in favor of the waqf's validity and irrevocability in accordance with the opinions of the two Great Masters mentioned above, his knowledge of the different opinions among the ancient Masters regarding the waqf notwithstanding]. ${ }^{49}$

48 The last part of the document was not available to me. For the sake of completion, I have reconstructed the following text by comparing with other similar cases found in the court records.

49 This procedure is typical of the Hanafĩ school as "Abū Ḥanifa asserted that a wakf is only irrevocable if the founder establishes it as from the moment of his death or if it is affirmed by a $k \bar{a} d \vec{\imath} \mathfrak{s}$ sentence. If a person founds a wakf during his lifetime, Abū Hanīfa holds that the $w a k f$ remains his property and he may revoke the wakf by alienating its property. After his death, the property reverts to his heirs. Establishing a wakf during one's lifetime is, in Abū Hanīfa's view, nothing else than a vow to donate the proceedings of the wakf property to the beneficiaries at the moment of one's death. This opinion, however, was not followed by his companions Muhammad al-Šaybānī and Abū Yūsuf, who held, like the jurists of the other legal schools, that establishing a wakf is an irrevocable and binding act. In order to dispel all doubts about the binding character of a wakf, Ḥanafì practice was for the founder to have recourse to judicial proceedings. The standard procedure was that the founder, after having handed over the wakf property to the administrator, would reclaim it alleging that the wakf was revocable according to Abu Hanifa's doctrine. The judge then would establish the irrevocability of the wakf by giving judgement according to the doctrine of Muḥammad al-Šaybānī and Abū Yūsuf and finding for the defendant." (Peters, s.v. "Waḳf" 3: p. 62). See also d'Emilia, A., "Il waqf ahli secondo la dottrina di Abū Yūsuf", Pubblicazione dell'Istituto di diritto romano e dei diritti dell'Oriente mediterraneo della Università di Roma, 6 (1938): pp. 67-87. 
What occurred was written and recorded upon request on the 12th day of the month of Rabīi I of the year 1066 [/9 January 1656].

ما في مطاوي هذا السفر الشرعي و محاوي...المريي من أصل الوقف و ضوابطه و شرائطه و التسبيل و قواعده و مصارفه حسبا بين و فصل في مطاويه على المطط



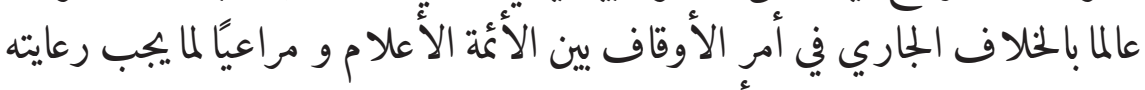

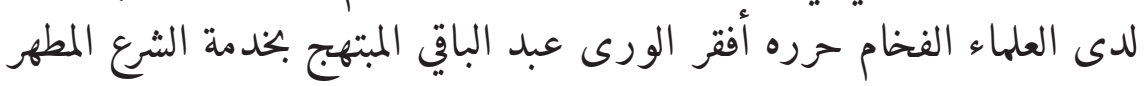

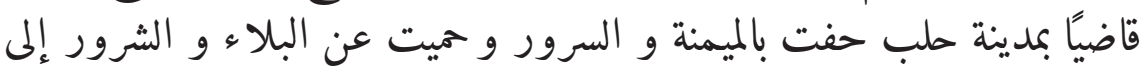

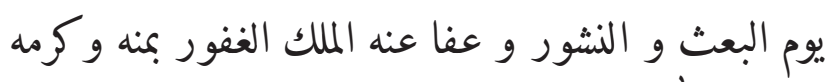

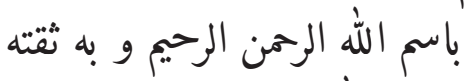



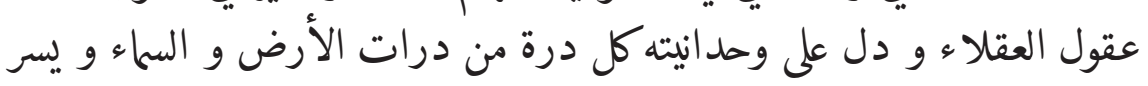

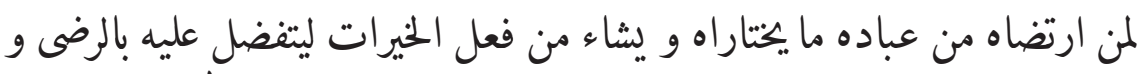

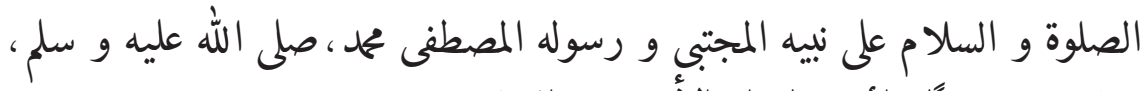

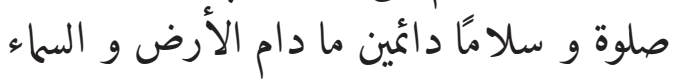
و بعد فقد حضر بمجلس الشرع الشريف و محفل الدين المنيف لدى متويله

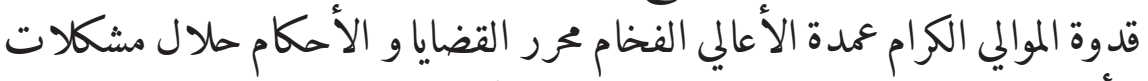



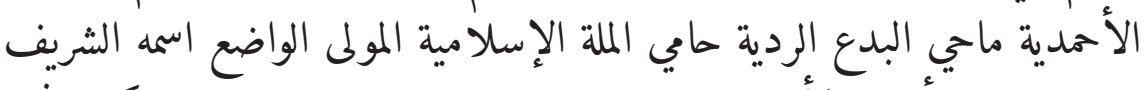





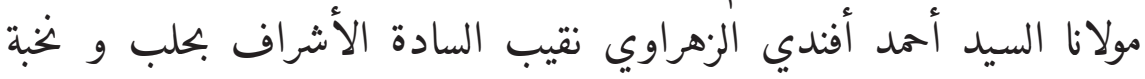

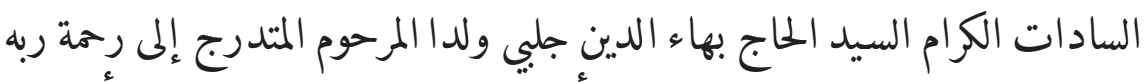

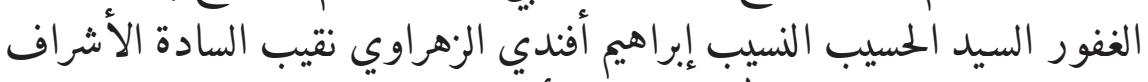

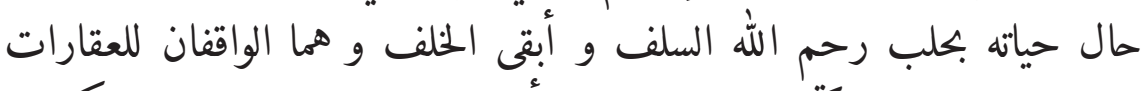

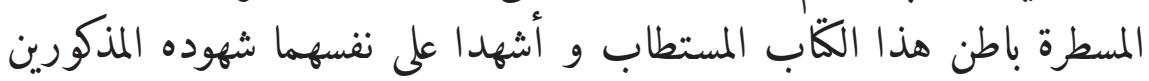


بذيله بأنهما قد وقفا أيضًا و حبسا و أبدا و خلدا بنية صادقة و طوية غير فاترة ما



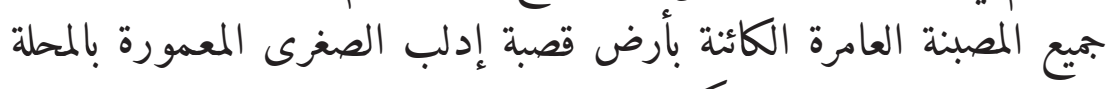

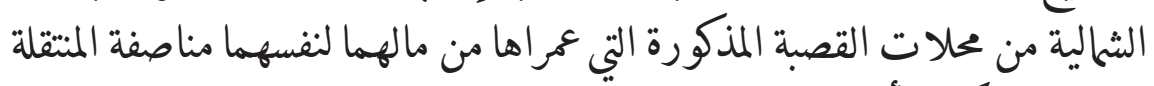

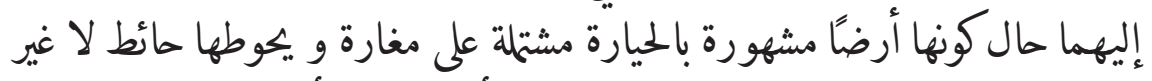

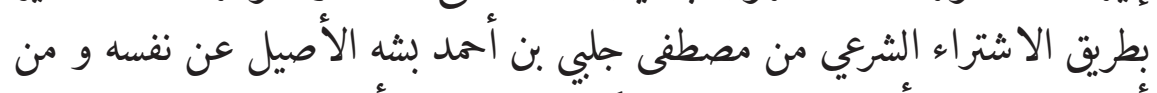

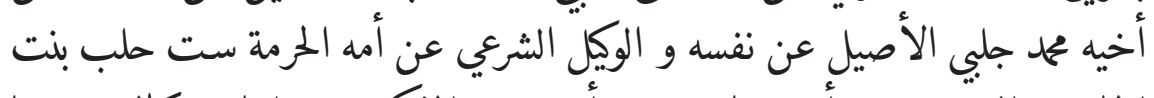



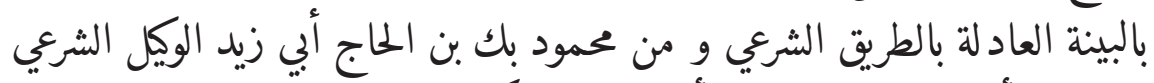

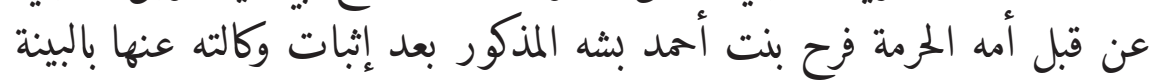



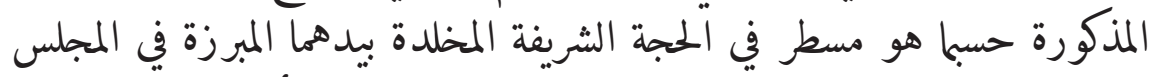

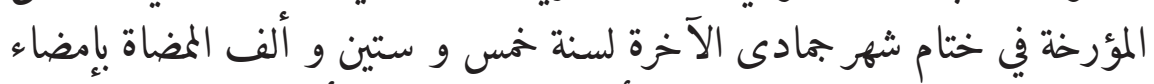

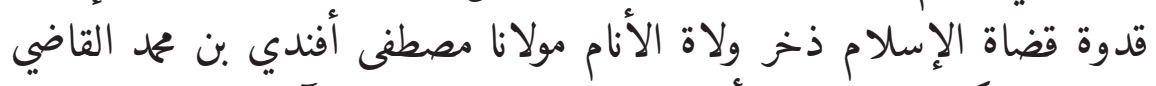

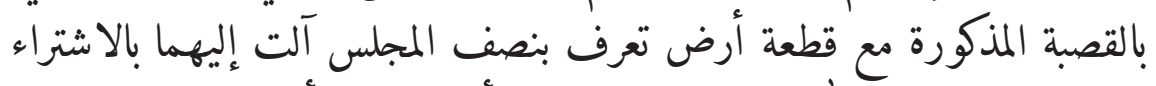

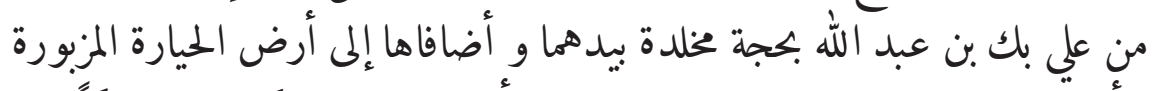

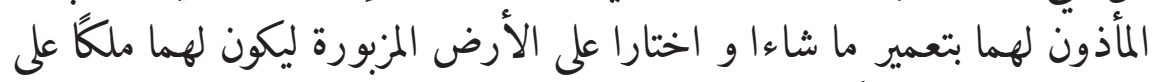

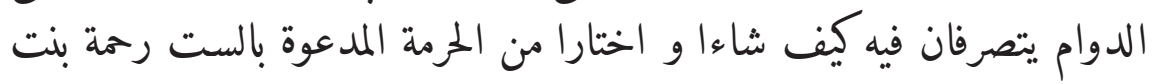

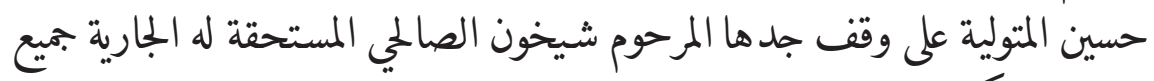

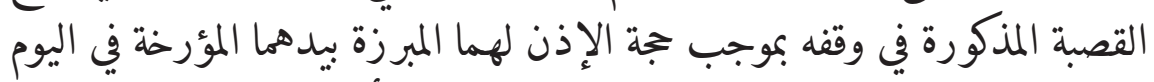

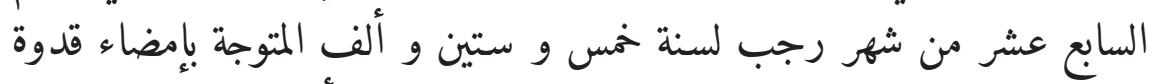

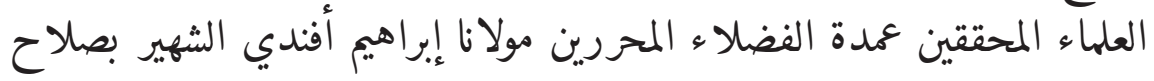

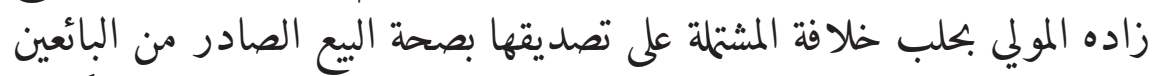

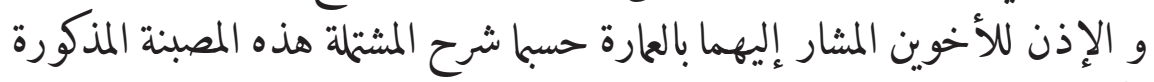

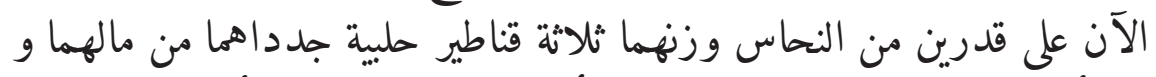



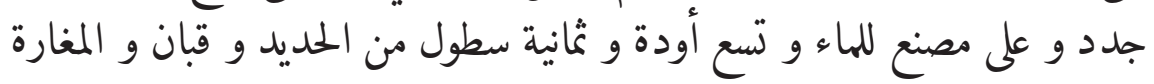


المذكورة و على حوش سماوي و فرين جدد للقدرين و على منافع و لوازم و

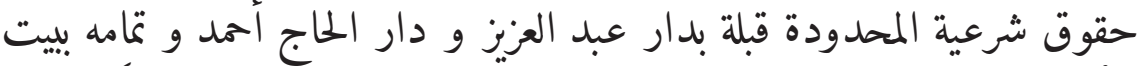

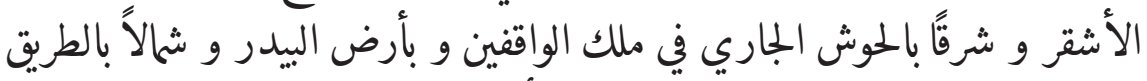

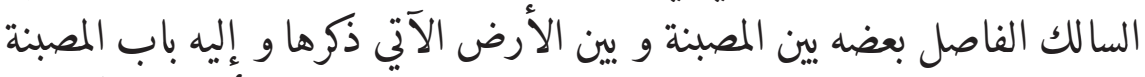

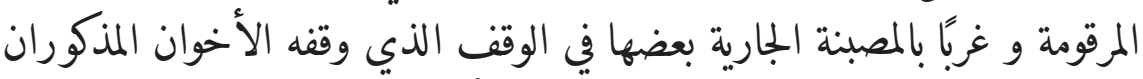

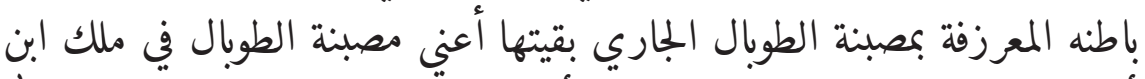

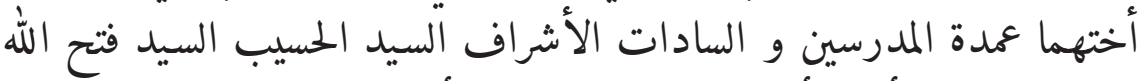

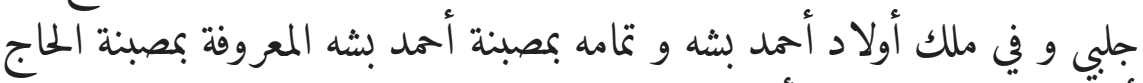

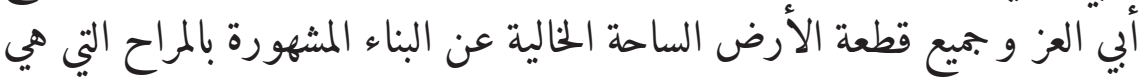

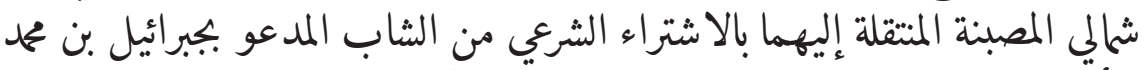

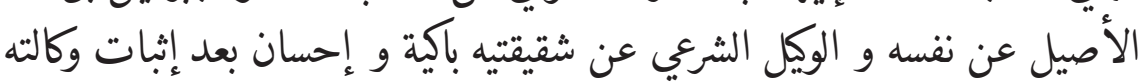
عنهما بالبينة العادلة بالطريق الشرعي حسبا هو مسطر في الحجة الشرعية المخلدة

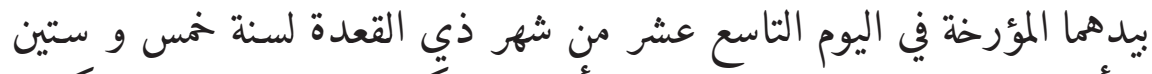

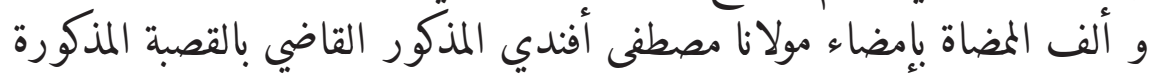

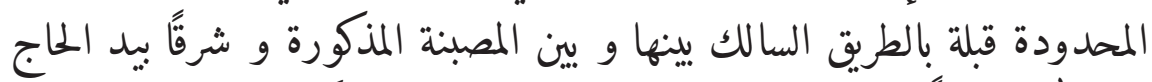



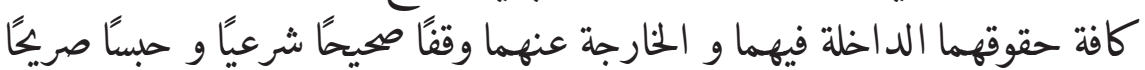

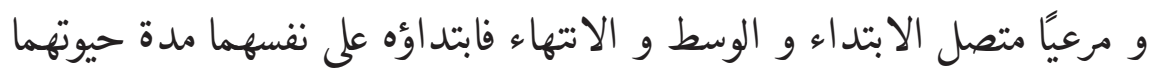

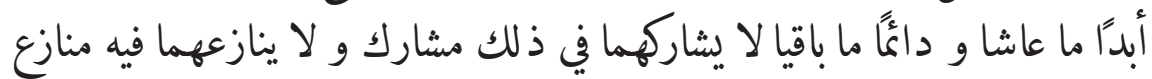



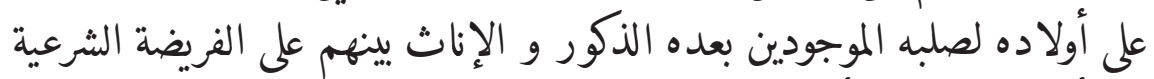

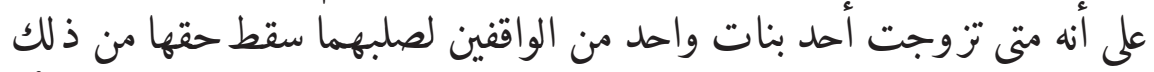

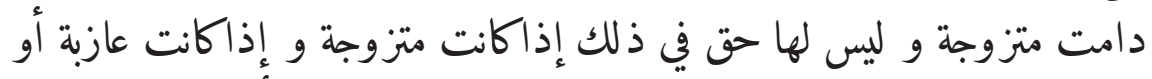
غير ذات بعل تستحق مع إخوتها ما عين لها و متى تزوج أحد بناتهما /بناتها

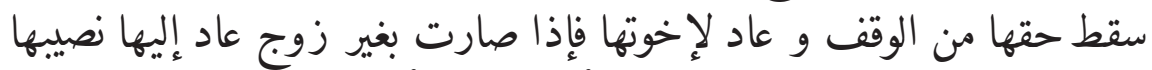

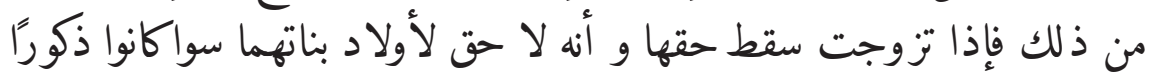

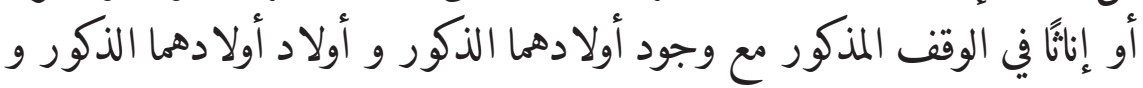


أولاد أولاد أولاد أولادهما الذكور ثم من بعد أولادكل واحد منهما من الذكور

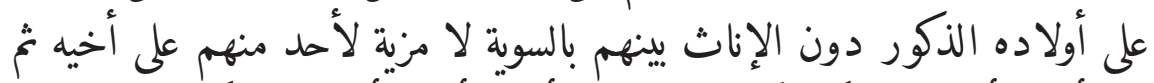



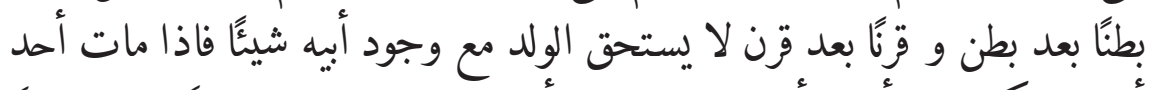

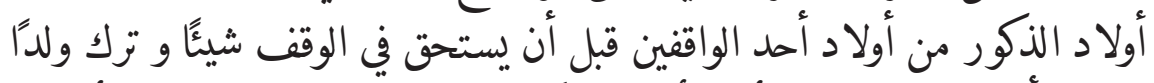

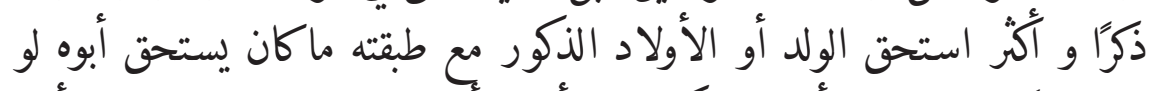

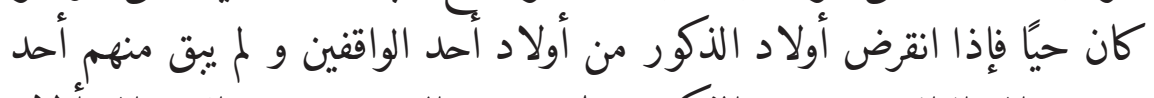

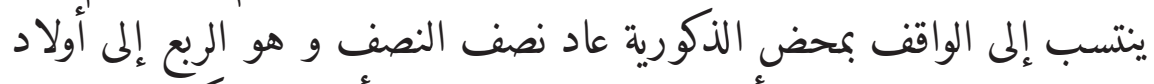



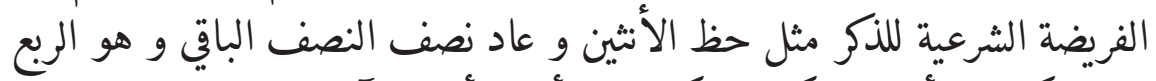

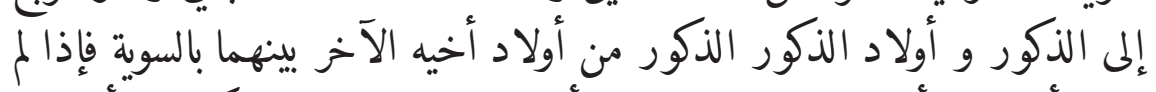

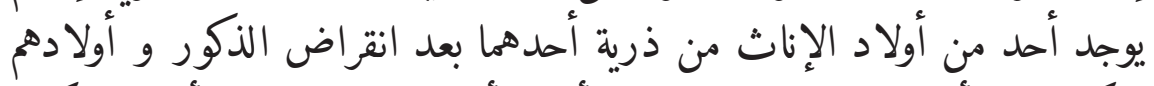

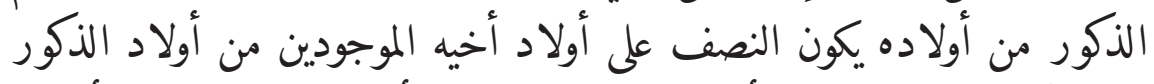

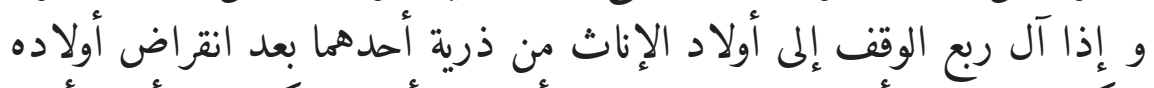

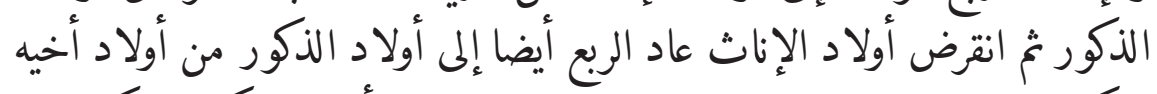

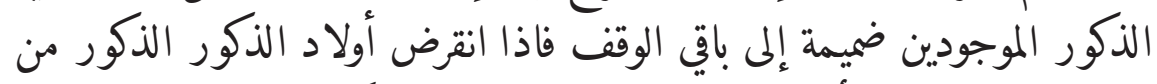

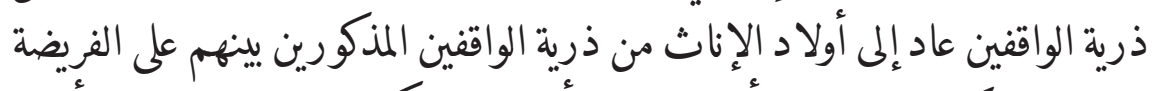

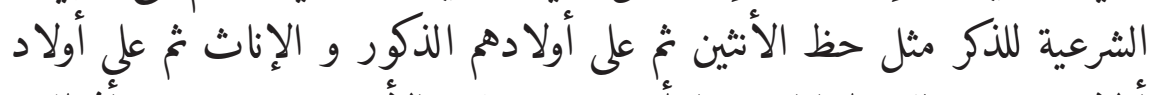

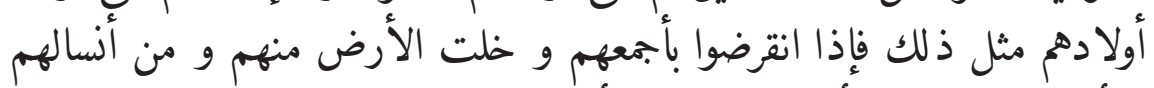

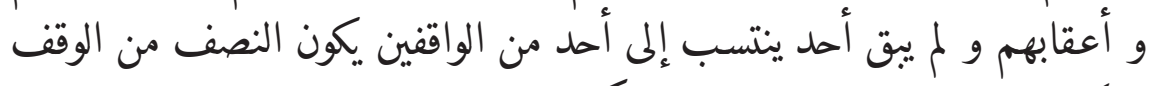

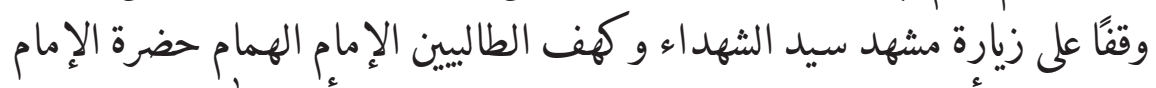

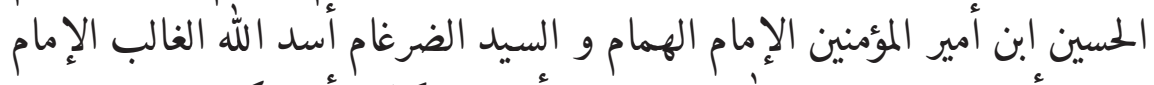



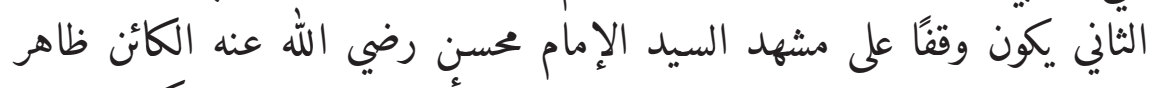

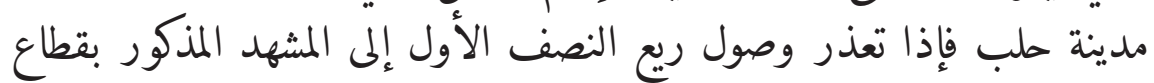

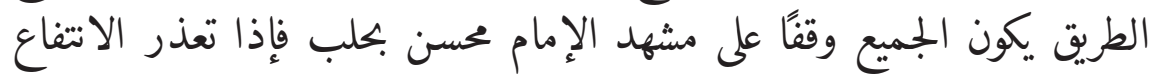




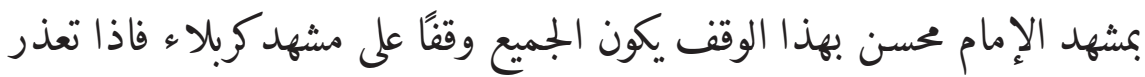



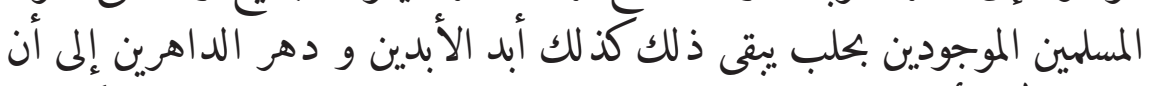

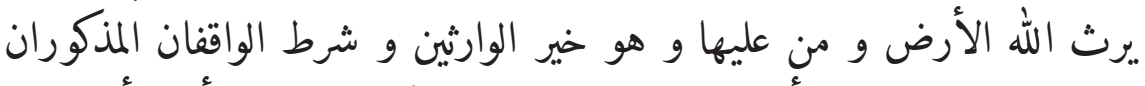

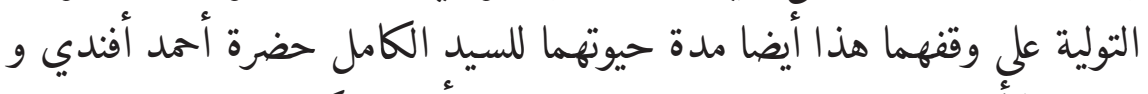



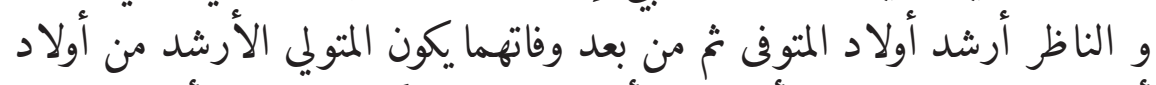

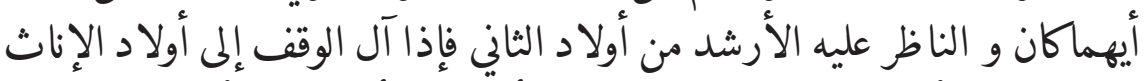

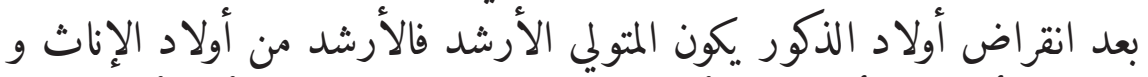

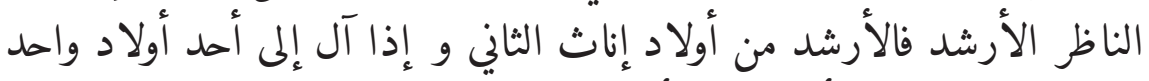

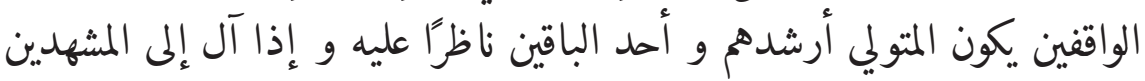

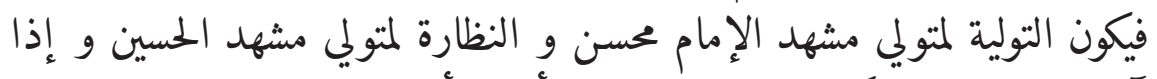

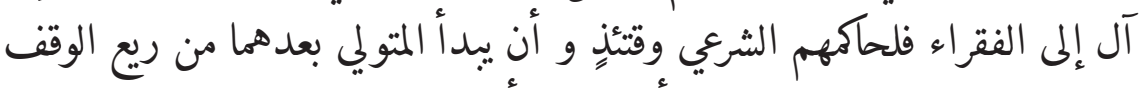

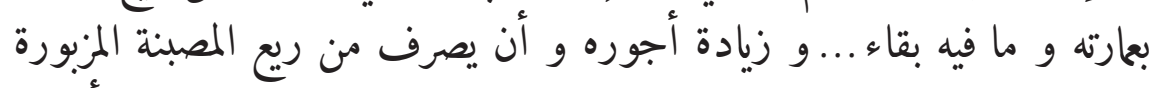

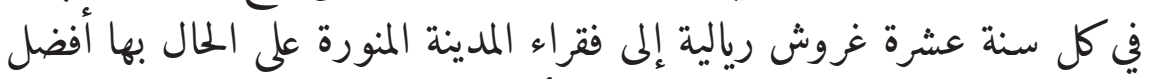

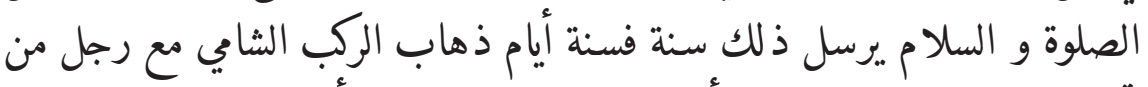

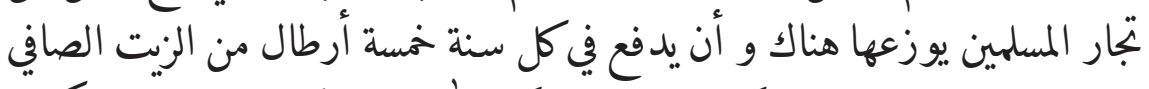

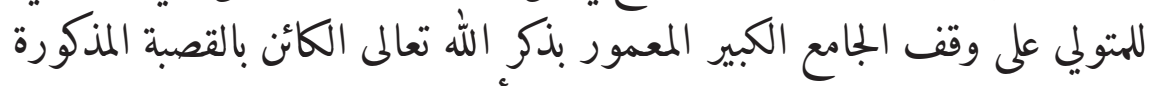

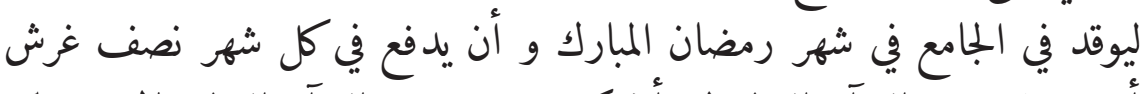



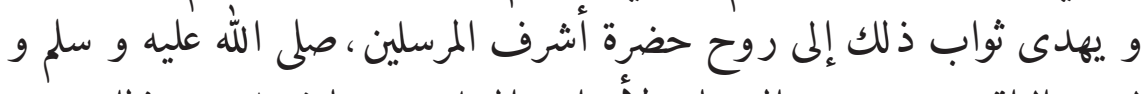

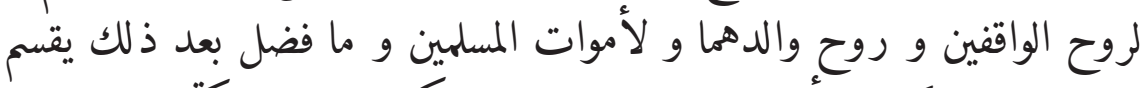

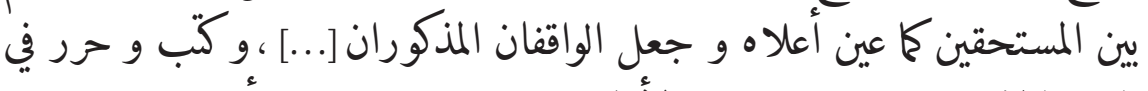

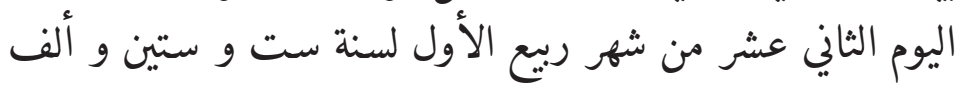




\section{Bibliographical Note}

\section{Primary Sources}

al-Ġazzī, K., Nahr al-dahab fìta'rīh Halab (3 vols., Halab: Dār al-Qalam al-'Arabī, 1999²). al-Ṭabbāh, M.R., I'lām al-nubalā bi-ta'rīkh Halab al-Šahbā' (7 vols., Ḥalab: Dār al-Qalam al'Arabī, 1988/1408²).

Munajjed, S., L’Acte de waqf du qāḍ̄ 'Uthmān b. al-Munağǧà (Damas: IFD, 1949).

Nașrallāh, I. Halab wa l-Tašayyu' (Bayrūt: Mu'assasa al-Wafā', 1983).

Qūṣarā, F., al-Raḥhāla fı muḥāfaza Idlib (2 vols., Dimašq: 1985-88).

\section{Secondary Literature}


et de Sayda (Ph.D. dissertation, Paris, 1976).

Abdul Tawab, A. and Raymond, André, "La waqfiyya de Muṣțafā Ğa ‘far", Annales Islamologiques, XIV (1978): pp. 177-93.

Algunduz, A., "Shari'ah Courts and Shari'a Records: The Application of Islamic Law in the Ottoman Empire", Islamic Law \& Society, XVI (2009): pp. 202-30.

Allen, T., Ayyubid architecture, online version, 2009, chap. 4-5: http://www.sonic .net/ tallen/palmtree/ayyarch/ (retrieved January 2017).

Baer, G., "The Waqf as a Prop for the Social System”, Islamic Law and Society, IV (1997): pp. 264-97.

Bayerle, G., Pashas, Begs and Effendis. A Historical Dictionary of Titles and Terms in the Ottoman Empire (Istanbul: Is Is, 1997).

Canbakal, H., "The Ottoman State and Descendants of the Prophet in Anatolia and the Balkans", JESHO, LII (2009): pp. 542-78.

Crecelius, D., "The waqfiyya of Muhammad Bey Abū al-Dhahab", Journal of the American Research Center in Egypt, XV (1978): pp. 83-105.

Douwes, D., History of the Alawis from medieval Aleppo to the Turkish republic (Princeton: Princeton University Press, 2016).

Douwes, D., The Ottomans in Syria: a history of justice and oppression (London: I.B. Tauris, 2000).

d'Emilia, A., "Il waqf ahli secondo la dottrina di Abū Yūsuf", Pubblicazione dell'Istituto di diritto romano e dei diritti dell'Oriente mediterraneo della Università di Roma, VI (1938): pp. 67-87.

Faroqhi, S., s.v. "Sidjill 3", $E I^{2}$, IX (1997): pp. 539-45.

Havemann, A., s.v. "Nakīib al-Ashrāf", $E I^{2}$, viI (1993): pp. 926-7.

Herzfeld, E., Materiaux pour un Corpus Inscriptiorum Arabicarum: deuxième partie: Syrie du Nord - Iscriptions et monuments d'Alep, I-II (Le Caire: IFAO, 1954). 
Hourani, A., "Ottoman Reform and the Politics of Notables", in Polk, W.R., Chambers, R.L., (eds.), Beginnings of the Modernization in the Middle East: The Nineteenth Century (Chicago and London: The University of Chicago Press, 1968): pp. 41-68.

Johnson, B.D., The Ottoman currency system (1687-1754) (Ph.D. dissertation, University of Washington, 1999).

Khayat, H.M., "The Si'ite Rebellions in Aleppo in the 6th AH/12th AD Century", Rivista degli Studi Orientali, XLVI (1971): pp. 167-95.

Little, D.P., "Haram documents related to the Jews of the late fourteenth century Jerusalem, Journal of Semitic Studies, xxx/2 (1985): pp. 227-64.

Marcus, A., The Middle East on the Eve of Modernity. Aleppo in the 18th century (New York: Columbia University Press, 1989).

Marino, B., Dalīl sijillāt al-maḥākim al-šariyya/Cataloues des Registres des Tribunaux Ottomans (Damas: IFEAD, 2000).

Massignon, L., s.v. "al-Muḥassin", $E I^{2}$ : VII (1995): p. 468.

Masters, B., The Arabs of the Ottoman Empire, 1516-1918: A Social and Cultural History (Cambridge: Cambridge University Press, 2013).

Masters, B., The Origins of Western Economic Dominance in the Middle East: Mercantilism and the Islamic Economy in Aleppo, 160o-1750 (New York and London: New York University Press, 1988).

Meriwether, M.L., The Kin Who Count. Family and Society in Ottoman Aleppo, 1770-1840 (Austin: University of Texas Press, 1999).

Morimoto, K., "A Preliminary Study on the Diffusion of the Niqāba al-Ṭālibiyyīn: Towards an Understanding of the Early Dispersal of Sayyids", in Kuroki, H. (ed.), The Influence of Human Mobility in Muslim Societies (London-New York-Bahrain: Routledge, 2003): pp. 3-42.

Morimoto, K., (ed.), Sayyids and Sharifs in Muslim Societies: Living Links to the Prophet (London: Routledge, 2012).

Muhammad Amin, N., "Un acte de fondation de waqf par une Chrétienne (Xe siècle h./ XVI ${ }^{\mathrm{e}}$ s. chr.), JEsHO, XVIII/1 (1975): pp. 43-52.

Mulder, S., The Architecture of Coexistence: Sunnis, Shi'is, and the Shrines of the 'Alids in the Medieval Levant (Ph.D. dissertation, University of Pennsylvania, 2008).

Mulder, S., The Shrines of the 'Alids in Medieval Syria: Sunnis, Shi'is, and the Architecture of Coexistence (Edinburgh: Edinburgh Series in Islamic Art, 2014).

Panetta, E., "Una waqfiyya hanafita del XVIII secolo", AION, III (1949): pp. 315-30.

Pascual, J.P., Damas à la fin du $16^{e ̀ ~ s i e ̀ c l e s ~ d ' a p r e ̀ s ~ t r o i s ~ a c t e s ~ d e ~ w a q f ~ o t t o m a n s ~(D a m a s: ~}$ IFEAD, 1983).

Peters, R., s.v. "Wakff”, $E I^{2}$, XI (2002): pp. 59-99.

Powers, D.S., "A court case from 14th century North Africa", JAOS, CX/2 (1990): pp. $\mathrm{xxx}-\mathrm{xxx}$. 
Rafeq, A.K, "The Law-Court Registers of Damascus", in Berque, J., and Chevallier, D., (eds.), Les Arabes par leurs Archives, XVI-XX s. (Paris: Publisher??? 1976): pp. 141-59.

Reilly, J., A small town in Syria. Hama in the 18th century (Oxford and Bern: Peter Lang, 2002).

Richards, D.S., "A Damascus Scroll Relating to a waqf for the Yūnusiyya", JRAS, CXXII/2 (1990): pp. 267-81.

Salati, M., "Ancora sui Zuhrazāda/Zuhrāwī di Aleppo: nuovi documenti dai tribunali sciaraitici (1706-1736)", Annali di Ca' Foscari, XLVI/2 (2007): pp. 73-108.

Salati, M., "I villaggi imamiti della provincia di Aleppo in epoca ottomana", Rivista degli Studi Orientali, LXIII/4 (1989): pp. 231-55.

Salati, M., "Note in margine ai Banū Zuhra/al-Zuhrāwī/Zuhrazāda di Aleppo: alcuni documenti dai tribunali sciaraitici della fine del XVII e l'inizio del XVIII secolo (1684-1701)", Annali di Ca' Foscari, XLIX/3 (2010 [Serie orientale, 41]): pp. 23-42.

Salati, M., "Note in margine alla storiografia musulmana su Aleppo: una lista di naqūb al-ašrāf del XVI e XVII secolo", Rivista degli Studi Orientali, LXIX/3-4 (1990):pp. 381-6.

Salati, M., "Nuovi documenti sui Zuhrāwī /Zuhrazāda di Aleppo (1699-1710)", Annali di Ca' Foscari, XXXViI/3 (1998): pp. 115-53.

Salati, M., "Šīism in Ottoman Syria: A Document from the Qādī-Court of Aleppo (963/1555)", Es, I.1 (2002): pp. 77-84.

Salati, M., "Toleration, Persecution, and Local Realities: Observations on Shiism in the Holy Places and the Bilād al-Shām", in La Šĭa nell'Impero Ottomano (Roma: Accademia dei Lincei, 1993): pp. 121-148;

Salati, M., "Tre documenti sull'uso della jizya nella Aleppo ottomana del XVII secolo", OM, XCIV (2014): pp. 176-85.

Salati, M., "Un documento sull'uso della hisba dai registri dei tribunali sciaraitici di Aleppo (1070/166o) conservato nella Biblioteca Nazionale 'Cirillo e Metodio' di Sofia”, in Papa, M., Scolart, D. and G.M. Piccinelli (eds.), Il Libro e la Bilancia. Scritti in memoria di Francesco Castro (2 vols., Roma: Istituto per l'Oriente "C.A. Nallino", 2011): I, pp. 299-304.

Salati, M., "Un ultimo documento sui Zuhrāwīzāda di Aleppo proveniente dai registri dei tribunali sciaraitici (1169/1751)", in Bredi, D., Capezzone, L., Dahmash, W., and L. Rostagno (eds.), Scritti in onore di Biancamaria Scarcia Amoretti (3 vols., Roma: Edizioni Q, 2008): III, pp. 1049-55.

Salati, M., "Urban Notables, Private Waqf and Capital Investment: The Case of the 17 th Century Zuhrāwī Family of Aleppo", Le Waqf dans l'éspace islamique. Outil de pouvoir socio-économique (Damas: IFEAD, 1995): pp. 187-201.

Salati, M., Ascesa e caduta di una famiglia di Ašrāf sciiti di Aleppo: I Zuhrāwī o Zuhrāzāda (160o-17oo) (Roma: Istituto per l'Oriente “C.A. Nallino”, 1992): pp. 10-18, 55-65 (Arabic translation, Āl-Zuhrāwī, Irtiqā' wa iktifā' 'à'ila min ašrāf wa nuqabā' Halab, al-Zuhrāwiyyūn aw Zuhrāzāda, 16oo-17oo, Homs: 2007). 
Salati, M., Documenti giuridici aleppini dei secoli XIV-XVII in materia di waqf (Roma: Istituto per l'Oriente "C.A. Nallino”, 1991).

Sauvaget, J., "Deux sanctuaires chiites à Alep”, Syria, IX/3 (1928): pp. 225-37, IX/4 (1928): pp. 320-7.

Scarcia Amoretti, B., "A proposito della comunità imamita contemporanea di Siria", oM, III (1984): pp. 193-201.

Schilcher, L., Families in politics: Damascene factions and estates of the 18th and 19th centuries (Stuttgart: F. Steiner Verlag, 1986).

Simsar, M.A., The Waqfyya of Ahmed Pasha (Philadelphia: University of Philadelphia Press, 1940)

Soberheim, M., "Das Heiligtum Šayh Muḥassin in Aleppo", in Mélanges H. Deremborg (Paris: 1940): pp. 379-90.

Soberheim, M., "Die Shī‘a in Aleppo", Der Islam, vi (1915): pp. 95-7.

Sourdel-Thomine, J., and Sourdel, D., "Biens fonciérs constitués en waqf en Syrie Fatimide pour une famille de Sharifs Damascains", Jes Ho, XV (1972): pp. 269-96.

Tate, J., Une waqfiyya du XVIII siècle à Alep. La Waqfiyya d'al-Hāğğ Mūsā al-Amìrī, (Damas: IFEAD, 1990).

Tülüveli, G., "Honorific titles in Ottoman parlance", International Journal of Turkish Studies, XI (2005): pp. 17-28.

Vajda, G., "Un act de waqf de Maras", Oriens, v (1952): pp. 47-59.

Venzke, M., The Ottoman Sanjaq of Aleppo (Ph.D. dissertation, Columbia University, New York, 1981).

Vesely, R., "Les requêtes en Egypte au XVIè siècle", REI, XLV (1977): pp. xxx-xxx?

Vesely, R., "Trois certificats délivrés pour les fondations pieuses en Egypte au XVI ${ }^{\mathrm{e}}$ siècle", Oriens, XXI-XXII (1968-69): pp. 248-99.

Wilkins, Ch., "The Self-Fashioning of an Ottoman Urban Notable: Ahmad Efendi Tahazāde (d. 1773)", Jos, XLIV (2014): pp. 393-425.

Wilkins, Ch., Forging Urban Solidarities. Ottoman Aleppo 1640-170o (Leiden: Brill, 2010). Winter, S., The Shiites of Lebanon under Ottoman Rule, 1516-1788 (Cambridge: Cambridge University Press, 2010).

Ze'evi, D., "The Use of Ottoman Shari'a Court Records as a Source for Middle Eastern Social History: A Reappraisal", Islamic Law \& Society, v (1998): pp. 35-56.

\section{Biographical Note}

Marco Salati is associate professor at the Ca' Foscari University of Venice. He published contributions about the history of 17 th and 18th-century Arab travelers in the Islamic East. His researches range from Shari'a and legal practice in Ottoman Aleppo to the wider study of the Shi'sm through the Ottoman empire. 